\title{
PERSOALAN MAGIS \\ DALAM KABA PUTI NILAM CAYO \\ KARYA SJAMSUDIN \\ SUTAN RAJO ENDAH \\ TINJAUAN SOSIOLOGI SASTRA
}

\section{Suria Dewi Fatma}

\begin{abstract}
This article describes magical contents in kaba Puti Nilam Cayo. Intrinsic aspects were analized with structural approach. After that, the results were analized with sociological approach. After all, this object describes magical contents as rutinity and as symbols. This kabashows Minangkabaunessebelievein supernaturalactivity in theiruniverse.
\end{abstract}

Key word: kaba, Minangkabau, Puti Nilam Cayo, sosiologi sastra

\section{Pengantar}

Kaba merupakan salah satu warisan budaya yang tumbuh dan berkembang dalam masyarakat Minangkabau. Pada mulanya, kaba disampaikan secara lisan oleh orang yang menghafalkan cerita, sehingga kaba ini terus hadir dalam kehidupan masyarakat Minangkabau secara turuntemurun dari satu generasi ke generasi berikutnya. Namun, dengan hadirnya pengaruh tulis baca dalam masyarakat Minangkabau, mengakibatkan sastra yang ada juga mengalami perkembangan. Perkembangan tersebut dapat dilihat pada penyampaian cerita kaba yang pada masa dahulunya adalah secara lisan, berubah secara bertahap ke dalam bentuk media cetak atau tulisan.

Kaba mengandung banyak falsafah hidup, pendidikan, dan pengajaran yang ditujukan untuk kaum muda maupun kaum tua. Kaba berisi tentang adat pergaulan, nasehat-nasehat, tanggung jawab serta kewajiban sosial antara mamak dan kemenakan, adat berumah tangga serta persoalan

WACANA ETNIK, Jurnal IImu Sasial dan Humaniora. ISSN 2098-8746.

Volume 1, Nomor 2, Oktober 2010. Halaman 141 - 154 
kehidupan sosial masyarakat Minangkabau secara umum. Pada kaba juga terdapat sindiran-sindiran (sindia), kiasan (kieh) sehingga pembaca harus berhati-hati mencari apa yang tersirat dibalik yang tersurat. Hal yang semacam ini memang telah menjadi kebiasaan orang Minangkabau, untuk tidak melahirkan secara terbuka sesuatu maksud yang hendak disampaikan (Manggis, 1979:18).

Diantara kaba-kaba klasik yang masih berkembang di Minangkabau, kaba Puti Nilam Cayo karya Sjamsudin St. Rajo Endah merupakan salah satu kaba yang cukup menarik untuk diteliti, karena kaba tersebut sarat dengan fenomena sosial yang masih relevan terjadi pada saat sekarang ini yaitu kepercayaan masyarakat terhadap tukang tenung ataupun ramalan. Dalam pandangan agama Islam tentunya kepercayaan yang seperti ini tidak dibenarkan, karena tidak sesuai dengan prinsip ajaran agama yang jelasjelas menduakan kekuasaan Tuhan.

Pada dasarnya kepercayaan masyarakat muncul karena terdapatnya beberapa bukti yang kuat, sehingga diyakini akan mendatangkan manfaat ataupun mudarat bagi masyarakat yang mempercayainya. Selain itu, kepercayaan masyarakat muncul tidak lain adalah untuk memenuhi rasa penasaran manusia dalam hal supranatural yang serba ganjil, dimana hal tersebut berkaitan dengan kejadian sehari-hari yang dialami dan ada di sekitar manusia itu sendiri. Intinya, segala sesuatu yang dianggap aneh atau ganjil akan dihubungkan dengan manusia di masa yang akan datang (www.primbon.com Beware: Primbon Sama dengan Warisan Jahiliah, 17 Desember 2009 pukul 14.30).

Walaupun hal tersebut terkesan tidak masuk akal, namun banyak diantara masyarakat kita yang percaya atau setengah percaya terhadap ramalan tersebut. Dengan demikian, tidak heran jika para dukun, tukang ramal dan tukang tenung tumbuh subur sehingga memiliki kedudukan tersendiri di lingkungan masyarakat. Peristiwa tersebut dihubungkan dengan kejadian yang ada disekitarnya, dengan kata lain mereka memvonis nasib seseorang dari tanda-tanda di tubuh, berdasarkan mimpi, bentuk wajah, garis tangan dan lain sebagainya.

Pada awalnya, kepercayaan animisme masyarakat muncul pada kalangan manusia primitif, dimana mereka mempercayai bahwa setiap benda di bumi ini seperti kawasan tertentu, goa, pohon atau batu besar mempunyai jiwa yang harus dihormati. Kepercayaan animisme ini juga mempercayai bahwa roh orang yang telah meninggal bisa masuk ke 
dalam tubuh hewan sehingga dianggap sakral (keramat) dan pantas untuk dihormati.

Selain dari jiwa dan roh yang mendiami tempat-tempat yang dinyatakan di atas, kepercayaan animisme juga mempercayai bahwa roh orang yang telah mati bisa masuk ke dalam tubuh hewan, misalnya suku Nias mempercayai bahwa seekor tikus yang keluar masuk dari rumah merupakan roh seorang wanita yang telah mati akibat melahirkan. Roh-roh orang yang telah mati, juga bisa masuk ke dalam tubuh babi atau harimau yang dipercaya akan membalas dendam kepada orang yang menjadi musuh bebuyutan semasa hidupnya.

Kepercayaan animisme ini berbeda dengan kepercayaan reinkarnasi seperti yang terdapat pada agama Hindu dan Budha, dimana dalam reinkarnasi jiwa orang yang telah mati tidak langsung pindah ke tubuh hewan lain yang masih hidup, melainkan mereka akan dilahirkan kembali dalam bentuk kehidupan lain. Pada agama Hindu dan Budha juga terdapat konsep karma. Karma dapat terjadi apabila seseorang melakukan kesalahan yang berakibat fatal, tidak hanya untuk dirinya sendiri maupun untuk orang lain misalnya kutukan.

Dalam fenomena inilah penulis mengangkat Kaba Puti Nilam Cayo ini menjadi objek penelitian, karena terdapat beberapa persoalan yang berkaitan dengan magis, kemudian direalisasikan dalam bentuk sesajen dan ritual. Pada dasarnya, masyarakat yang beragama Islam tidak akan menanggapi hal yang demikian, karena mereka diwajibkan mempercayai dan meyakini bahwa Tuhan adalah sang pencipta alam semesta. Meyakini suatu hal yang datang dari praduga atau fikiran manusia, akan dianggap menyekutukan kekuasaan Tuhan. Tentunya hal tersebut berdampak buruk bagi generasi muda dimasa yang akan datang.

\section{Landasan Teori}

Teori sosiologi sastra digunakan sebagai analisis terhadap karya itu sendiri, terutama yang berkaitan dengan persoalan magis. Teori tersebut berangkat dari realitas dan kondisi masyarakat yang terdapat dalam suatu teks karya sastra yaitu sampai sejauh mana karya sastra tersebut dapat mencerminkan kehidupan masyarakat setidak-tidaknya gambaran tentang diri pribadi seseorang.

Menurut Abrams (dalam Nurgiyantoro, 1995:36) sebuah karya sastra fiksi atau puisi menurut kaum strukturalisme adalah sebuah totalitas yang 
dibangun secara koheren oleh berbagai unsur pembangunnya. Disatu pihak, struktur karya sastra dapat diartikan sebagai susunan, penegasan, dan gambaran semua bahan serta bagian yang menjadi komponennya secara bersama membentuk kebulatan yang indah. Dipihak lain, struktur karya sastra juga menyarankan pada pengertian hubungan antar unsur (intrinsik) yang bersifat timbal balik, saling menentukan, saling mempengaruhi dan secara bersama-sama membentuk satu kesatuan yang utuh.

Analisis struktural dalam karya sastra dapat dilakukan dengan mengidentifikasi, mengkaji dan mendeskripsikan fungsi dan hubungan antar unsur intrinsik fisik yang bersangkutan. Mula-mula diidentifikasi dan dideskripsikan bagaimana keadaan peristiwa, tokoh dan penokohan, latar, sudut pandang, dan lain-lain. Setelah dijelaskan fungsi masingmasing unsur tersebut dalam menunjang makna keseluruhannya, maka secara bersama akan membentuk sebuah totalitas kemaknaan yang padu, misalnya hubungan antar peristiwa yang satu dengan peristiwa yang lainnya, kaitannya dengan pemplotan yang tak selalu kronologis, kaitannya dengan tokoh dan penokohan, dengan latar dan sebagainya (Nurgiyantoro, 1995:37).

Namun yang lebih penting adalah bagaimana menunjukkan hubungan antar unsur tersebut dan sumbangan apa yang diberikan terhadap tujuan estetik dan makna yang ingin dicapai. Hal ini perlu dilakukan karena karya sastra merupakan sebuah struktur yang kompleks dan unik, disamping setiap karya mempunyai ciri yang komples dan unik. Hal inilah yang membedakan antara karya yang satu dengan karya yang lainnya (Nurgiyantoro, 1995:38).

Menurut Koentjaraningrat (1996:16) sosiologi merupakan cabang dari ilmu filsafat yang memisahkan diri dari ilmu khusus, sedangkan sastra adalah lembaga sosial yang menggunakan bahasa sebagai mediumnya dan bahasa itu sendiri merupakan ciptaan sosial (Damono, 1979:1). Dengan demikian, sosiologi sastra adalah salah satu teori yang dalam pendekatannya mempertimbangkan segi-segi kemasyarakatan, yaitu sejauh mana karya sastra dapat mencerminkan kehidupan masyarakat setidak-tidaknya gambaran tentang diri pribadi seseorang.

Menurut Wellek dan Warren (1989:111) terdapat tiga bagian sosiologi sastra diantaranya :

1. sosiologi pengarang, sosiologi pengarang berhubungan dengan pengarang dalam menciptakan karya sastra dan faktor yang 
mempengaruhinya.

2. sosiologi karya, sastra dianggap sebagai cerminan dalam masyarakat dan sampai sejauh mana sastra itu mencerminkan realitas dari masyarakat.

3. sosiologi pembaca, sosiologi pembaca lebih memfokuskan pada perhatian pembaca dan pengaruh karya tersebut terhadap pembacanya.

Berdasarkan pembagian di atas, terdapat tiga penggarapan dari sosiologi sastra yakni: pengarang, karya, dan pembaca. Dalam penelitian ini penulis lebih menekankan pada pendekatan sosiologi karya, yakni sampai sejauh mana karya sastra tersebut mencerminkan realitas dari masyarakat. Metode ini digunakan untuk mengetahui struktur dan gejala sosial di luar sastra, sehingga mendapatkan gambaran tentang cara-cara tokoh cerita dalam menyesuaikan diri dengan lingkungan dan masyarakat pendukung kebudayaannya (Damono, 1984:6).

\section{Unsur Intrinsik Kaba Puti Nilam Cayo}

Tokoh Gombang Alam tidak menunjukkan perkembangan yang berarti, karena tokoh ini bersifat datar dan tidak ada satu pun sifat yang berubah dalam dirinya. Hal yang serupa juga terjadi pada karakter Puti Ambun Suri, Puti Andam Dewi, Puti Nilam cayo dan Rambun Sati.

Hanya saja karakteristik dari Rajo Alam Sati, Sutan Rajo Angek dan tukang tenung yang mengalami perubahan sikap. Hal ini dapat dilihat ketika Rajo Alam Sati mengusir Gombang Alam dan Puti Ambun Suri untuk keluar dari istana. Hal ini dikarenakan oleh fitnah dari tukang tenung yang meramal nasib Puti Ambun Suri ketika itu. Sementara tukang tenung hanyalah sebagai orang suruhan yang wajib melaksanakan perintah dari Rajo Angek sekalipun bertentangan dengan hati nuraninya sendiri. Dengan demikian tokoh yang berwatak bulat hanyalah tertuju pada tiga tokoh tersebut.

Keterkaitan tokoh dengan persoalan magis dapat dilihat melalui tindakan yang dilakukan para tokoh yang turut mengalami suatu proses di dalam cerita dan negeri-negeri yang tidak dapat kita temukan pada saat sekarang ini seperti negeri Saribunian, negeri Pantai Ameh, negeri Mandang Kamulang dan negeri Camin Talayang.

Melalui perjalanan yang panjang, seorang tokoh dapat menemukan pengalaman yang menarik mulai dari suka dukanya kehidupan sampai mendapatkan sesuatu yang paling berharga, seperti tongkat keramat, mustika naga hingga ia dinobatkan sebagai seorang raja di negeri Camin 
Talayang. Tentunya semua itu tidak lepas dari perantara gajah keramat yang pada waktu itu dipercaya dapat mencari sosok seorang raja yang tepat untuk memimpin negeri tersebut.

Begitu pula halnya dengan tokoh lainnya seperti Ambun Suri, Rambun Sati, Puti Nilam Cayo, tukang tenung dan pertapa sakti. Mereka mengalami suatu perjuangan dan perjalanan yang panjang, hingga mereka diyakini dan diakui keberadaannya di tengah-tengah masyarakat. Tentunya semua itu berkaitan langsung dengan peristiwa yang terjadi pada saat itu.

Latar tempat mengisyaratkan pada lokasi terjadinya peristiwa yang diceritakan dalam sebuah karya fiksi. Unsur tempat yang dipergunakan dapat berupa tempat-tempat dengan nama-nama tertentu, inisial tertentu dan lokasi tertentu. Latar kaba Puti Nilam Cayo digambarkan oleh pengarang pada suatu daerah yang terdapat di Minangkabau pada masa dahulu yaitu di negeri Saribunian. Penggambaran latar ini disampaikan oleh pengarang sebagai pembuka cerita.

Lokasi ini merupakan tempat kediaman Rajo Alam Sati dan Puti Andam Dewi. Di tempat ini Gombang Alam dan Puti Ambun Suri dilahirkan dan dibesarkan. Tempat ini merupakan saksi bisu atas terusirnya Gombang Alam dan Puti Ambun Suri dari istana oleh fitnah dari para tukang tenung. Tempat ini juga merupakan puncak dari malapetaka yang menimpa Rajo Alam Sati dan akhirnya menyadari kekhilafan yang telah dilakukan terhadap kedua anaknya.

Selain dari negeri Saribunian, juga terdapat beberapa tempat yang menjadi tujuan dari Gombang Alam dan Puti AmbunSuri dalam melakukan pengembaraan diantaranya negeri Pantai Ameh, negeri Mandang Kamulang (tempat kediaman Puti Nilam Cayo) dan negeri Camin Talayang yaitu tempat dimana Gombang Alam dinobatkan sebagai raja di negeri tersebut.

Latar waktu berhubungan dengan kapan terjadinya peristiwaperistiwa yang diceritakan dalam sebuah karya fiksi. Masalah kapan tersebut berhubungan dengan waktu faktual, atau waktu yang ada kaitannya dengan peristiwa sejarah. Jika dilihat dari kehidupan keseharian para tokoh cerita, baik berupa kebiasaan hidup, dari tingkatan atau jabatan dapat dipastikan bahwa kaba ini berlatarkan Islam. Keberadaan agama Islam dapat ditelusuri melalui ucapan para tokoh cerita yang selalu menyatakan kebesaran dan kekuasaan Allah.

Walau agama Islam menjadi panutan oleh masyarakat di negeri tersebut, namun masih ditemukan adanya paham animismeatau kepercayaan 
masyarakat terhadap hal-hal yang gaib di luar batas kemampuan manusia. Hal ini hanya dapat dilakukan oleh para tukang tenung yang merupakan orang pilihan dari seluruh penjuru negeri. Gajah keramat, tongkat keramat, naga keramat dan mustika naga merupakan sesuatu hal yang diyakini memiliki kemampuan tanpa batas, sehingga diyakini akan mendatangkan manfaat bagi orang atau masyarakat yang memilikinya. Latar waktu juga dapat berupa hitungan jam, nama-nama hari, bulan dan peredaran matahari. Penjelasan tentang latar waktu ini disampaikan oleh pengarang secara ekplisit misalnya pada waktu siang hari, "hari nan sadang tangah hari (hari yang sedang tengah hari), paneh sarupo mambalah banak (panas seperti membelah benak)" (Hal.9). Pada waktu malam hari juga diungkapkan dengan "hari samalam-malam nantun (hari semalam-malam itu), laruik malam mangko talalok (larut malam maka tertidur)" (Hal.11). Pengungkapan sore hari menjelang senja adalah dengan "lah patang candonyo hari (telah petang sepertinya hari), patang bajawek dangan sanjo (petang berjawab dengan senja)" (Hal.18).

Latar waktu dalam cerita ini sama seperti biasa seperti, wakatu tangah hari (waktu siang hari), samalam-malam nantun (waktu malam) dan lah patang candonyo hari (waktu sore menjelang senja). Waktu berdasarkan peredaran matahari misalnya, pado hari nan sahari nantun (pada hari yang sehari itu), hari barisuak (besok hari), patang pagi siang malam (petang pagi siang malam), paneh sarupo mambalah banak (panas seperti membelah benak), matohari sapanggalan tagak (matahari sepenggalan tegak). Hitungan hari dengan jumlah hari, jumlah bulan dan tahun diungkapkan dengan, alah sahari duo hari (telah sehari dua hari), hari barisuak (besok hari), habih pakan baganti pakan (habis pekan berganti pekan), alah sahari pajalanan (telah sehari perjalanan), lah cukuik umua tujuah hari (telah cukup umur tujuh hari), lah cukuik tujuah kali maadokan rapek (telah cukup tujuh kali mengadakan rapat), lah cukuik bilangan salapan hari (telah cukup bilangan delapan hari), lah sampai bilangan bulan (telah sampai bilangan bulan), alah sabulan duo bulan (telah sebulan dua bulan), lah tigo bulan nagari indak barajo (telah tiga bulan negeri tidak ada raja), cukuik sambilan bulan papek (cukup bilangan sembilan bulan), bulan sadang limo baleh (bulan sedang lima belas), alah satahun antaronyo (telah setahun antaranya), lah cukuik duo tahun papek (telah cukup bilangan dua tahun), lah cukuik umua limo tahun (telah cukup umur lima tahun), habih tahun baganti tahun (habis tahun berganti tahun), lah limo tahun inyo disinan (telah lima tahun dia disana). 


\section{Persoalan Magis}

Kaba Puti Nilam Cayo ini berlatar sosial Minangkabau pada masa dahulu, dimana dalam lingkungan ini terdapat kultur dan ragam dari status sosial masyarakat. Status sosial ini terlihat dimana orang miskin akan dipandang sangat hina oleh kalangan masyarakat, sedangkan orang yang harkat martabatnya lebih tinggi akan mendapat perlakuan yang khusus dalam masyarakat itu sendiri.

Latar sosial ini juga tidak lepas dari persoalan magis yang terdapat di dalam masyarakat. Pada dasarnya masyarakat merupakan penggerak dari suatu kebudayaan. Tanpa adanya masyarakat, mustahil segala macam ritual magis dapat dilaksanakan. Dari kepercayaan masyarakat, kemudian berkembang menjadi suatu keharusan yang wajib dilaksanakan, seperti halnya ucapan para tukang tenung dan pertapa sakti.

Pada dasarnya persoalan magis adalah hal-hal yang berhubungan dengan kemampuan di luar batas kemampuan manusia biasa. Tentunya kemampuan ini hanya dimiliki oleh orang-orang yang memiliki kelebihan. Dalam Ensiklopedia Indonesia (Syadili, 1987) magis adalah cara-cara tertentu yang diyakini dapat menimbulkan kekuatan gaib sehingga orang yang mempraktekkannya dapat menguasai orang lain baik dalam pikiran maupun tingkah lakunya.

Dalam persoalan magis, terdapat suatu proses yang turut berperan serta dalam rutinitas yang dijalankan. Proses tersebut dapat berupa hubungan interaksi yang terjalin antara masyarakat yang satu dengan masyarakat yang lainnya. Tentunya, hal ini juga berhubungan dengan animisme dan dinamisme yang terdapat di dalam masyarakat itu sendiri.

Animisme adalah kepecayaan terhadap makhluk halus atau roh yang dianggap memiliki kekuatan sakti seperti tumbuh-tumbuhan dan binatang, Sedangkan dinamisme menurut Sampurna (www.google.com animisme dan dinamisme, tanggal 27 Desember 2009 pukul 20.00) adalah suatu kepercayaan bahwa segala sesuatu mempunyai tenaga atau kekuatan yang dapat mempengaruhi keberhasilan atau kegagalan usaha manusia dalam mempertahankan hidup. Dengan kata lain, dinamisme berhubungan langsung dengan kepercayaan masyarakat terhadap benda-benda tertentu yang dianggap memiliki kekuatan gaib, seperti halnya benda-benda bertuah.

Berangkat dari penjelasan di atas, tentunya hal ini tidak lepas dari ritual magic yang dijalankan oleh masyarakat. Ritual tersebut dapat berupa 
pemujaan, perlengkapan sesajen dan lain sebagainya. Dalam pandangan agama Islam, tentunya kepercayaan terhadap animisme dan dinamisme ini tidak dibenarkan karena termasuk ke dalam perbuatan syirik. Apabila manusia tunduk kepada sesuatu hal selain Allah, maka dapat dipastikan bahwa mereka telah menyalahi fungsinya sebagai makhluk Tuhan.

Dalam kaba Puti Nilam Cayo ini mayoritas masyarakatnya adalah beragama Islam, karena berdasarkan pada kepercayaan masyarakat terhadap Tuhan yaitu sang pencipta alam semesta. Hal ini seiring dengan pandangan hidup masyarakat yang bersesuaian dengan falsafah Minangkabau yaitu adat basandi syarak, syarak basandi kitabullah. Dengan kata lain, agama dijadikan sebagai patokan dan landasan hukum yang berlaku dalam masyarakat itu sendiri. Hal ini juga sejalan dengan "syarak mangato, adat mamakai". Syarak mangato artinya syarak memerintahkan melalui Alquran dan Hadis Nabi. "Adat mamakai" artinya adat melaksanakan perintah dari syarak tersebut.

Masyarakat Minangkabau, berpegang teguh pada ajaran agama yang berlaku dan meyakini akan adanya kekusaan Tuhan yang tidak terbatas. Agama Islam menjadi kepercayaan masyarakat Minangkabau, didasarkan atas banyaknya kesamaan dan kearifan. Selain mengedepankan ketulusan akhlak dan budi, penganut agama Islam juga dituntut untuk menjalankan dan mengembangkan ajaran agama ke arah yang lebih baik.

Dalam agama Islam juga tidak terdapat unsur pemaksaan terhadap barang sesuatu hal, asalkan masih berada pada koridor yang semestinya. Masyarakat Minangkabau tidak mengakui seseorang atau sekelompok orang yang tidak beragama Islam. Artinya, orang yang tidak memeluk agama Islam tidak dapat dikatakan sebagai orang Minang.

Fenomena sosial baru dapat dipahami apabila kita berhasil memahami makna yang tersimpan dalam diri para pelakunya. Dari berbagai peristiwa yang terjadi, maka akan terlihat apa yang melatarbelakangi tindakan sosial yang terjadi dalam masyarakat (Bungin dkk, 2003:26). Dalam Kaba Puti Nilam Cayo terdapat beberapa gambaran fenomena sosial masyarakat Minangkabau yang sesuai dengan konsep sastra yang mencerminkan masyarakat pada masa tertentu (Junus, 1984:57).

Walaupun demikian kaba ini tidaklah mencerminkan keadaan sosial masyarakat Minangkabau secara menyeluruh, karena sebuah karya sastra terlihat sangat kompleks dan mendetail dalam memperlihatkan kondisi zamannya, namun hal tersebut tidak dapat dijadikan patokan 
untuk gambaran masyarakat pada saat itu. Pada dasarnya, karya sastra sudah dipengaruhi oleh unsur imajinasi seorang pengarang supaya dapat dinikmati oleh pembacanya, sehingga pesan yang ingin disampaikan oleh pengarang dapat diterima secara baik oleh masyarakat.

Persoalan magis dalam Kaba Puti Nilam Cayo, juga tidak terlepas dari gejala-gejala sosial masyarakat yang melatarbelakanginya, seperti manusia keramat, tongkat keramat, naga keramat, mustika naga dan gajah keramat.

\section{Manusia Keramat}

Manusia keramat yang dianggap membawa berkah bagi kedua orang tuanya dan masyaarakat adalah Gombang Alam, Puti Ambun Suri, tukang tenung dan petapa sakti. Gombang Alam dikatakan anak keramat karena ketika proses kelahirannya terdapat tanda-tanda yang aneh, sehingga diyakini mendatangkan manfaat dan berkah untuk orang lain.

Puti Ambun Suri merupakan seorang anak yang juga dianggap keramat. Hal ini terlihatketika Rajo AlamSatimencoba untukmemenggalnya seiring dengan isi ramalan yang diucapkan oleh para tukang tenung. Pada dasarnya para tukang tenung mendapat ancaman dari Rajo Angek yang pada waktu itu berkuasa. Ia terkenal dengan tindakan dan kezaliman yang cukup menakutkan kalangan masyarakat. Para tukang tenung diminta berkata bohong dari isi ramalan tersebut.

Para tukang tenung merupakan orang yang memiliki kekuatan sakti, dimana mereka dapat meramalkan nasib seseorang dan nasib suatu negeri dimasa yang akan datang. Peran sertanya di dalam masyarakat, tak jarang mendapatkan tempat tersendiri. Mereka dipercaya dengan kelebihan dan kemampuan di dalam meramal nasib seseorang. Tentunya, kelebihan tersebut diiringi dengan aktivitas dan berbagai perlengkapan untuk memulai ritual seperti kitab nujum dan kemenyan putih. Para tukang tenung merupakan orang pilihan yang dapat memberikan berbagai informasi terhadap suatu kondisi atau pun peristiwa yang akan terjadi.

Tak jarang ucapannya menjadi keharusan yang wajib dilaksanakan oleh masyarakat. Hal ini terbukti dengan hasil ramalannya yang tepat, akurat dan benar-benar terjadi di dalam kehidupan masyarakat. Namun berbeda dalam ramalan kali ini, dimana para tukang tenung dipaksa untuk berkata bahong terhadap ramalan Puti Ambun Suri ketika itu.

Petapa sakti merupakan orang yang miliki kemampuan dan ilmu yang tinggi. Ia dapat berpindah-pindah sesuai dengan keinginannya 
sendiri. Namun lebih banyak menghabiskan waktunya dengan bertapa dan meditasi. Tujuannya adalah untuk menjauhkan diri dari hal-hal yang bersifat keduniawian. Petapa sakti juga memiliki benda keramat yang turut mengiringinya selama proses pengembaraan seperti tongkat keramat.

Pada masanya, petapa sakti inilah yang akan memberikan pertolongan kepada Gombang Alam dan Puti Nilam Cayo untuk keluar dari pulau yang tidak berpenghuni tersebut. Petapa sakti juga menyarankan Gombang Alam untuk mencari naga keramat yang berada di dasar lembah, serta mengambil mustika naga yang berada di rahang naga tersebut.

\section{Tongkat Keramat}

Tongkat keramat adalah benda bertuah yang dimiliki oleh petapa sakti. Kesaktian tongkat tersebut dapat mengalahkan segala macam jenis binatang buas baik yang berbisa maupun tidak berbisa. Kesaktian tongkat keramat ini juga dapat melumpuhkan segala jenis lawan atau musuh yang ditemui ketika berada di dalam hutan. Kelak tongkat inilah yang digunakan oleh Gombang Alam untuk melumpuhkan kekuatan naga keramat.

\section{Naga Keramat dan Mustika naga}

Naga keramat merupakan binatang sakti. Biasanya ia hidup di lembah-lembah perbukitan. Hal yang sering menjadi incaran dari para pemburunya adalah mustika naga yang berada di rahang naga tersebut. Konon, mustika naga dapat mengabulkan segala macam permohonan yang kita harapkan. Dengan kata lain mustika naga dapat mengabulkan segala permintaan yang kehendaki.

Mustika naga memiliki peran serta yang luar biasa. Dimana mustika naga merupakan benda yang paling dibanggakan dan berharga bagi Gombang Alam. Tanpa bantuan mustika naga, mustahil Gombang Alam dapat melakukan segala sesuatu dengan sebaik-baiknya. Dengan kata lain, segala hal yang dilakukannya hanyalah berasal dari pertolongan mustika naga, tidak murni dari usaha yang ia lakukan sendiri.

\section{Gajah Keramat}

Gajah keramat merupakan binatang yang paling sakral dan paling dipercaya di negeri Camin Talayang. Gajah keramat baru bisa digunakan apabila telah terjadi suatu peristiwa besar di negeri tersebut. Pelepasan gajah keramat juga tidak lepas dari ritual yang mengiringinya seperti kemenyan 
putih serta setanggi harum-haruman untuk memulai ritual yang akan dilakukan. Peristiwa besar itu terjadi ketika raja yang memimpin negeri tersebut telah meninggal dunia dan tidak memiliki pewaris atau keturunan untuk mewarisi tahta kerajaan.

Dapat dipastikan segala macam kegiatan yang hendak dilakukan akan menjadi terhambat. Aktivitas kerajaan akan menjadi fakum dan berdampak buruk bagi kelangsungan kerajaan serta masyarakat dimasa yang akan datang. Ini merupakan bukti yang nyata, bahwa tidak akan mungkin suatu sistem pemerintahan akan berjalan lancar tanpa adanya figur dari seorang pemimpin.

Atas peristiwa tersebut, maka barulah gajah keramat dapat dilepaskan tentunya melalui aturan adat yang berlaku di dalam masyarakat. Konon gajah keramat dapat mencari sosok pengganti seorang raja yang tepat untuk memimpin negeri Camin Talayang.

\section{Penutup}

Dalam persoalan magis, terdapat beberapa hal yang menunjang suatu proses dimana masyarakat meyakini dan mengkeramatkan barang sesuatu seperti kepercayaan terhadap manusia keramat, tongkat keramat, naga keramat dan mustika naga serta gajah keramat. Kepercayaan muncul karena terdapat beberapa bukti yang kuat sehingga diyakini akan mendatangkan manfaat untuk orang lain. Dengan kata lain masyarakat merupakan promotor dan penggerak dari suatu kebudayaan.

\section{DAFTAR PUSTAKA}

Damono, Sapardi Djoko. 1979. Sosiologi Sastra Sebuah Pengantar Ringkas, Jakarta: Pusat Pembinaan dan Pengembangan Bahasa Departemen Pendidikan dan Kebudayaan.

Junus, Umar. 1984. Kaba dan Sistem Sosial Minangkabau Suatu Problema Sosiologi Sastra. Jakarta: Balai Pustaka.

Koentjaraningrat. 1996. Pengantar Antropologi I. Jakarta: Djambatan.

Nurgiyantoro, Burhan. 1995. Teori Pengkajian Fiksi. Yogyakarta: Gadjah Mada University Press.

Sutan Rajo Endah, Sjamsuddin. 2004. Kaba Puti Nilam Cayo. BukittinggiSumatera Barat: CV. Kristal Multi Media.

Syadili, Hasan (Red). 1987. Ensiklopedia Indonesia. Jakarta: Ichtiar Bru-Van Hoeve

Wellek Rene dan Austin Warren. 1993. Teori Kesusastraan, Jakarta: PT. 
Persoalan Magis ...

Gramedia Pustaka Utama.

www.primbon.com Beware Primbon Sama Dengan Warisan Jahiliah. 17 Desember 2009

www.google.com Animisme dan Dinamisme. 27 Desember 2009. 
